\title{
1. Surface Tension, Screen Space
}

\author{
Giuliana Bruno
}

\begin{abstract}
My work questions how material relations can appear on the surface of different media — on film and video screens, in gallery installations, or on the skins of buildings and people. In response to these issues, I propose to approach materiality as a surface condition. Focusing on screen surface, I show that technologies of light can produce new forms of materiality. In this text, the screen emerges as a site of encounter and admixture. Various experiments of screening are considered, ranging from those envisaged by László Moholy-Nagy to the contemporary installations of Krzysztof Wodiczko. In these configurations of the act of screening, different forms of mediation, memory, and transformation can take place. This is what I call 'the surface tension of media'.
\end{abstract}

Keywords: Screen, materiality, surface, media, moving image installation art, László Moholy-Nagy, Krzysztof Wodiczko

There exist what we call images of things, Which as it were peeled off from the surfaces Of objects, fly this way and that through the air. [...] I say therefore that likenesses or thin shapes Are sent out from the surfaces of things Which we must call as it were their films or bark. ${ }^{1}$

For Lucretius, the image is a thing. It is configured like a piece of cloth, released as matter that flies out into the air. In this way, as the Epicurean philosopher and poet suggests to us, something important is shown: the

Sæther, S.Ø. and S.T. Bull (eds.), Screen Space Reconfigured. Amsterdam: Amsterdam University Press, 2020 DOI 10.5117/9789089649928_CHO1 
material of an image manifests itself on the surface. Lucretius describes the surface of things as something that may flare out, giving forth dazzling shapes. It is as if it could be virtually peeled off, like a layer of substance, forming a 'bark' or leaving a sediment, a veneer, a 'film'. This poetic description and its philosophical fabrication go to the heart of my concern in this text, which addresses matters of surface and especially of screen fabric.

In reflecting on the configuration of the screen, I expand here upon a central concern of my book Surface: Matters of Aesthetics, Materiality, and Media, in which I turn to the concept of surface in order to investigate the place of materiality in our contemporary world. ${ }^{2}$ In this age of virtuality, with its rapidly changing materials and media, what role can materiality have? How is it fashioned in the arts or manifested in technology? Could it be refashioned? I ask these questions at a time when contemporary artists themselves appear preoccupied with materiality in different forms and are questioning the material conditions of their mediums. Take, for example, Francis Alÿs' moving-image work REEL-UNREEL (2011), an homage to the resilience of cinema as a cultural archive. The camera follows a reel of film as it unrolls through the old part of Kabul, pushed by children like a hoop to create an improvised narrative of the city. Here, at the very moment of film's obsolescence or demise, a reel of film can take on a particular significance and can be refashioned into a different object as it becomes transformed into a way of unfolding space and reimagining urban relations. I argue that, in this transformative way, there is potential for a reinvention of materiality in our times. In claiming that it is visibly and actively pursued in the visual arts and in residual and textural forms, I set out to open up a space for its theorization. Most important, I contend that materiality is not a question of the materials themselves but rather concerns the substance of material relations. I am interested in the space of those relations and in showing how they are configured on the surface of different media.

In thinking about the surface of things, the architect Le Corbusier wrote that 'architecture being [...] the magnificent play of masses brought together in light, the task of the architect is to vitalize the surfaces which clothe these masses'. ${ }^{3}$ This idea inspires the theoretical direction I propose in approaching materiality as a surface condition. The surface is here configured as an architecture: a partition that can be shared, it is explored as a primary form of habitation for the material world. Understood as the material configuration of the relationship between subjects and with objects, the surface is also viewed 


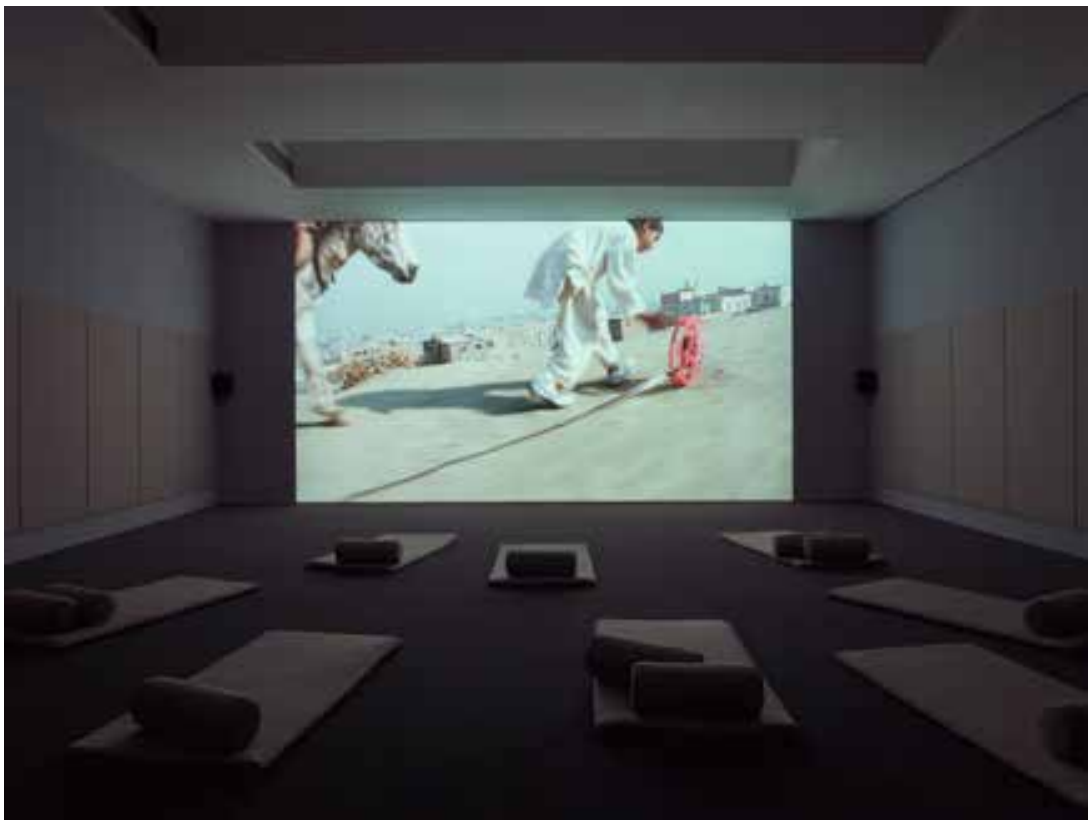

1. Francis Alÿs (in collaboration with Julien Devaux and Ajmal Maiwandi), REEL-UNREEL, 2011. Video installation, 19:00. Installation view, Francis Alÿs: REEL-UNREEL, David Zwirner, New York, 2013.

(c) Francis Alÿs. Courtesy of the artist and David Zwirner. Photo: Maris Hutchinson / EPW Studio

as a zone of encounter and admixture, a site of mediation and projection, memory and transformation. Furthermore, as we consider that art, architecture, fashion, design, film, and the body all share a deep engagement with superficial matters, we can also observe how surfaces act as connective threads between art forms and how they structure our communicative existence.

This larger theoretical premise about surface materiality leads me to consider the material condition of the film medium and to specifically address the surface of the screen. I propose making a material turn in visual studies in order to vitalize the surfaces that clothe the material of our objects and to show that, in our times, materiality manifests itself in projection, in the surface tension of media. In particular, I aim to theorize the screen as an environment of 'projection', understanding projection in the largest sense of the term - as an architecture of passage - while highlighting texture and materiality, surface, and light. Projection is indeed a space of relations, and it is becoming an actual environment. Architects are increasingly turning the façades of their buildings into screens, making them into translucent surfaces as permeable and layered as skins, and artists are reinventing the art of projection. We as visual theorists can contribute concrete reflections on these intersecting architectures if we think further of our own reflective surface: the projective mode and visual 
plasticity, the sartorial texture and opaque transparency - that is, the luminous material transference- that is our medium.

It is time to design an alternative genealogy for the screen, not simply conceived as a window or a mirror. Departing from the metaphors of optical framing that have long circulated in film theory, I propose to think haptically of a luminous screen-membrane or screen-fabric. In fashioning the projective space in this way, I mean to emphasize the surface condition, the textural manifestation, and the support of a work as well as the way in which it is sited and mobilized in space. I am particularly interested in the play of materiality that is brought together in light on different 'screens', and in offering a theorization of the actual material fabric of the screen, outside of figuration. I am also interested in exploring the migratory patterns of such visual fabrications, and in tracing their material histories. This investigation of screen cultures thus concerns the archaeology of media as well as their shifting geographies.

Such concern for a material geography runs deeply in my work. From an early call to exit the prison-cave of the movie house, I have worked to affirm the hapticity and mobility of film architectures through an expanded notion of cinema. The act of 'streetwalking around Plato's cave' suggested a desire to explore film not as an isolated and enclosed domain but rather as a mobile, shifting terrain. ${ }^{4}$ In further mapping the projective space, I have emphasized that the activity of projection includes a psychic interplay and modalities of affect as well as other relationships. Screens are a moving architecture in which spectators are engaged and participate in constructing environments of 'public intimacy'. ${ }^{5}$ In other words, screens are spatial formations that are relational.

This geography of exhibition suggests that cinema is a variegated landscape, for there is a historical variety of moving-image exhibition in space. The function of the screen cannot be understood if we ignore that cinema is materially connected to other forms of display and if we overlook a consideration of these modes of exhibition. Screens are in fact a material architecture that emerges in dialogue with other arts and exhibition practices-including, historically, the birth of the museum. The public museum was in fact configured in its modern form in the same age of visual display that gave rise to the cinema, the defining art of modernity, and it shares with film that surface of communication that is the visual, theatrical architecture of spectatorship. The cultural function of the screen evolves in conjunction with the visual arts and in interaction with their surfaces and volumes. 
To recognize this relationship of art to film exhibition is particularly relevant in any attempt to address contemporary culture. When we approach the visual architecture of our times, we confront a hybrid, shifting landscape. Modes of reception in the visual arts and media are becoming more fluid and increasingly mobile. The exhibition of film images has exited the space of the movie house; screens have multiplied, and different forms of viewership and locales have emerged. As moving images have migrated, they have established a solid presence as light spaces in the art gallery and the museum. As a result, film itineraries have become increasingly linked to museum walks. This migration of screens has strengthened the relationship between art, architecture, and moving images. The architectural wall and the gallery wall are not only becoming more like light spaces, they are at times even turning into literal screens.

It is therefore crucial that we consider the geography and mobility of exhibition and engage closely in matters of surface and screen space by making a material turn in visual theorization. In order to address the projective space more concretely, I will now turn to a specific aspect of material culture and tackle the material history of the screen. We will look at its emergence as a medium and outline an experimental theorization of its architectural surface to construct a different materiality for the screen. The excursus that follows begins with the archaeology of the act of screening and then links avant-garde experiments in screening to our contemporary, mobile forms of exhibition. In linking pre-filmic to post-filmic conditions, and concluding with contemporary moving-image installation art, I aim to further highlight the shifting history of the screen surface, its textural quality, and fundamental hybridity as a projective space.

\section{Media Archaeology of the Screen}

In developing the notion that the screen is an architecture and, in turn, creates an environment, it is fruitful to engage the form of its material history, for it displays aspects of a cultural history. The history of the screen is inscribed in what Jacques Rancière calls the 'surface of design', and it is written into the interesting, morphing etymology of the word screen. ${ }^{6}$ The origin of the term points to a great variety of mediums, surfaces, and types of screening, mostly emerging from the material world of architecture.

6 Rancière, The Future of the Image, pp. 91-108. 


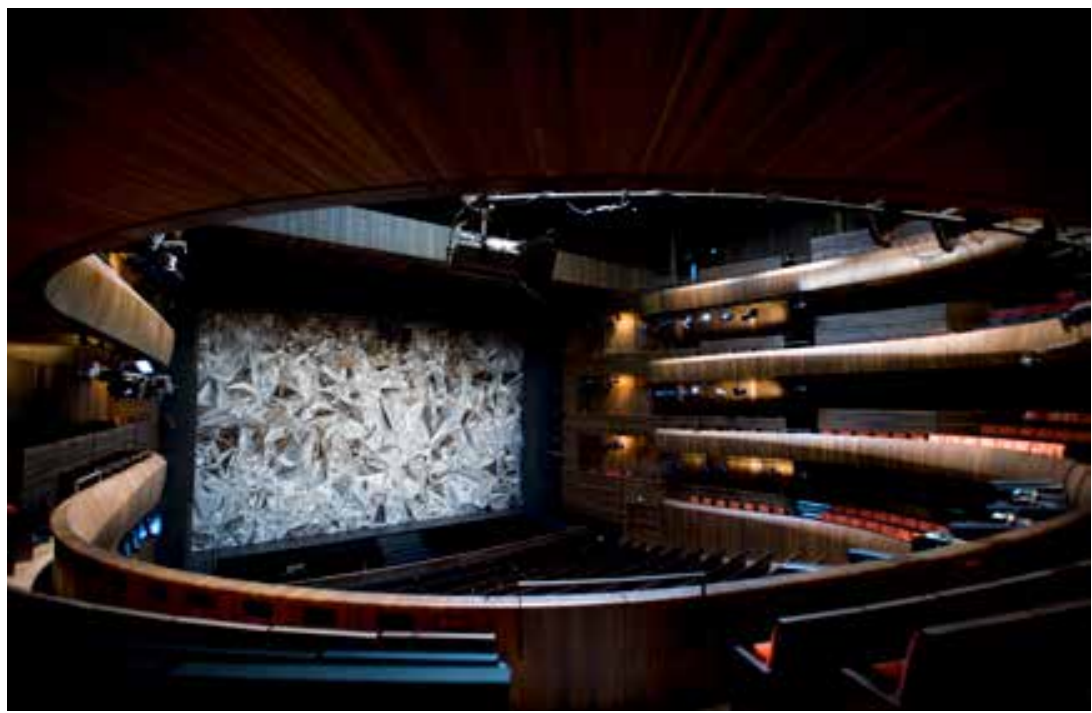

2. Pae White, MetaFoil, 2008. Cotton, wool, polyester, and Trevira, $2895 \mathrm{~cm}$ x $1097 \mathrm{~cm}$. Stage curtain for the Oslo Opera House theatre. Photo: Erik Berg. Courtesy of the artist, the Norwegian National Opera and Ballet, Public Art Norway, and neugerriemschneider, Berlin.

The word screen appeared during the Renaissance, evolving from an earlier Germanic root that also transferred to Latin languages. It usually designated, as Erkki Huhtamo shows, 'a floor-standing piece of furniture, consisting of a sheet of lighter, often translucent material (paper, some kind of fabric) stretched on a wooden frame (or series of connected, folding frames)'. ${ }^{7}$ By the nineteenth century, this fabrication of the screen-its textural materiality - unfolded into a new kind of fabric. The form of a translucent membrane interestingly expanded to encompass a surface of projection. Joining architecture to precinematic media, the term arrived at defining a plane for the transmission of luminous images. It is significant to note that The Century Dictionary and Cyclopedia, published originally in 1899, defines the screen first architecturally, as 'a covered framework, partition or curtain [...]; as, a fire-screen; a folding-screen; a window-screen', but then includes in this form of observational veiling of space 'a screen upon which images can be cast by a magic lantern'. ${ }^{8}$

7 Huhtamo, 'Elements of Screenology', p. 35. For an overview of various aspects of screen studies, see Kuhn, ed., Screen. For a treatment of the screen as form, see, among others, Paul, 'Screening Space', pp. 244-274; Wasson, 'The Networked Screen', pp. 74-95; and Friedberg, The Virtual Window.

8 As cited in Huhtamo, 'Elements of Screenology', p. 31. 
The history of the screen's evolution teaches us that what we now call screen, and understand to be a projective surface, originated in the world of objects, material space, and interior design. The screen was a thing. It was an object of furniture, a domestic item that inhabited interiors. It specially acted to negotiate inside and outside, and it materially transformed space. When deployed to divide space in the home, a screen mediated between private and public zones of habitation and could create privacy and intimacy. The folding screen often presented itself as a framed surface that filtered and diffused light and was also richly illustrated with images. Its fabric quality emerged from its being also a form of window dressing. The screen was even more than a visual fabric, however. It was a piece of material culture, a matter of decoration and adornment. And this ornament could be ornate in many ways. There were portable versions of it in the form of hand-screens, which could even respond to a personal ornamental desire. In its many configurations, the screen had a real plastic visibility, and yet it was an imaginary structure. Its material substance could activate, animate, and mediate the dimension of the imagination. In other words, the screen was a veritable piece of 'interior' design.

It was this particular object of décor that made possible a visual, imaginary passage, in such a way foreshadowing our current sense of what a screen is and what potential forms of 'projection' it may hold for the future. It is such a thing that we find both reflected and projected in our own screen world. When encountering the screen as an object, in fact, we can experience at a tangible level how the fabric of the screen-its projective potential—stems from a history of folding together architecture and interior design with moving images in luminous forms of imaginary projection. From the very beginning, the screen was constituted as a space of passage in which art forms could become connected.

This material history shows us that the screen is a space of crossovers in which the visual and the spatial arts come into dialogue. The screen is a vessel: it is the material support onto which proliferations of images can come into being and, in luminous passage, also flow in time across media conditions. As such a material medium connecting art, architecture, and film, the screen is a stretchy fabric: it is the site of intermedial projections. On this pliant, reflective surface, mediatic shifts can take place materially, becoming palpable to our senses in surface tension.

In probing the 'surface of design', we can sense the variety of intermedial transits that are written on screen surface. When we trace the history of its design form, we can expose the rich potential of screen space, including how it functions as a passage, a transitional site, and even a relational space. If 
I keep pursuing 'the surface of design', it is because, as Rancière notes, 'by distributing surfaces, one also designs partitions that enable one to partake in communal space, [...] configurations of what can be seen and what can be thought, forms of inhabiting the material world'. ${ }^{9}$ Forms of 'superficial' envelopment in the visible world involve the sensible realms of texture and inhabitation. Theorizing the screen in this way, I want to emphasize that the surface comes into play here as a partition in which one can partake. It 'mediates' by acting as a material configuration of how the visible meets the thinkable and as a form of sensible dwelling in the material world.

\section{The Screen in Experimental Film Theory}

To advance further in this material theorization of the screen as a transitional architecture and to design screen space as an environment, we can also take a cue from the poet and critic Vachel Lindsay. In 1915, when Lindsay offered his pioneering theorization of cinema in his book The Art of the Moving Picture, he recognized the capacity of the screen to be an architecture of passage and to cross over between interior and exterior worlds. ${ }^{10} \mathrm{He}$ located such capacity in the profound hybridity of this form. For Lindsay, the possibility of crossing worlds afforded by the art of the moving picture was inseparable from a motion across art forms. In pointing to the potential of the filmic screen, he described its material form as 'sculpture-in-motion', 'painting-in-motion', and 'architecture-in-motion' and even considered the screen a form of 'furniture-in-motion'. ${ }^{11}$ In emphasizing how the screen constitutes an architecture-in-motion, he called attention to its capacity to create and convey surfaces and textures. On the surface of the screen, Lindsay affirmed, 'tones, textures, lines, and spaces take on a vitality almost like that of flesh and blood'. ${ }^{12}$

A few years later, the tensile hybridity of the screen as a form of projection came to be theorized and practiced in the work of László Moholy-Nagy. A transdisciplinary artist who pursued his ideas in mediums extending from painting to photography to design, Moholy-Nagy considered light

9 Rancière, The Future of the Image, p. 91 (English translation modified slightly by the author. Original English translation: 'distributing surfaces, one also designs divisions of communal space. [...] configurations of what can be seen and what can be thought, certain forms of inhabiting the material world.').

10 Lindsay, The Art of the Moving Picture.

11 Ibid., see chapters 8, 9, 10, and 11.

12 Ibid., p. 95. 


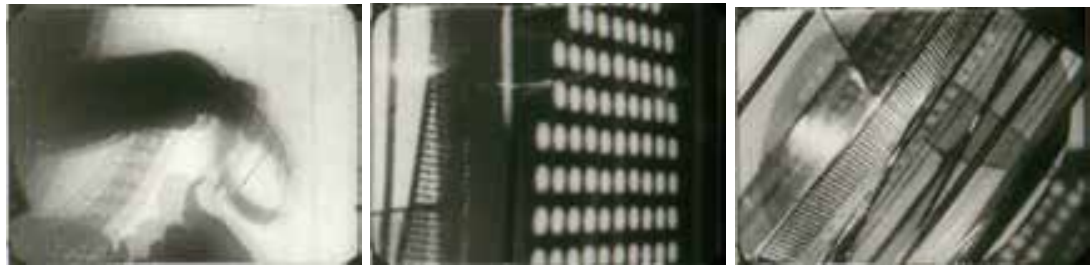

3. László Moholy-Nagy, Ein Lichtspiel schwarz weiss grau (Lightplay Black White Gray), 1930.

Black-and-white film, silent, 6 min. Film stills. Courtesy of Harvard Film Archive.

to be a material connection between media. His kinetic sculpture LightSpace Modulator, which was made into a film in 1930, explored light as an architecture, in moving, projected form. For this artist, light was not only a space per se but something that could transform - modulate - sites as a tangible material of projection.

In his book Painting Photography Film, published in 1925, Moholy-Nagy articulated this spatial modulation theoretically. ${ }^{13}$ Here, light becomes the connecting thread between film, photography, and painting, insofar as it is an essential material condition of viewing. Light is a sensitive material that appeared creatively in painting to activate a sense of vision in motion before it was acted upon chemically in the age of mechanical reproduction. Moholy-Nagy connects together 'Painting with Pigment to Light Displays Projected. ${ }^{14}$ He theorizes luminosity across media and texturally relates 'the material pigment and the material light'. 15

Speaking about painting with light in his 1936 essay 'Light Architecture', Moholy-Nagy further interweaves painting, film, and architecture, proposing to transform bidimensionality into a plastic, luminous plane with a form of projection that would animate all of their surfaces. ${ }^{16}$ Different textures might be created, he contends, with materials that respond to projected light in such a way that the surfaces could change and morph. Moholy-Nagy makes painting, architecture, and film into surfaces of movement and potential transformation by emphasizing the textural as a quality in these media that capture luminous spectrums. ${ }^{17}$

13 Moholy-Nagy, Painting Photography Film. Antonio Somaini provides a useful commentary in his introduction to the Italian edition. See Somaini, 'Fotografia, cinema, montaggio', pp. ix-xi.

14 Moholy-Nagy, Painting Photography Film, p. 11.

15 Ibid., p.12.

16 Moholy-Nagy, 'Light Architecture', pp. 15-17. On Moholy-Nagy's engagement with exhibition, see Elcott, 'Rooms of Our Time', pp. 25-52.

17 On this subject see Smith, 'Limits of the Tactile and the Optical', pp. 6-31. The essay shows the extent of Moholy-Nagy's interest in materiality and texture as it continued also through the work of his students, including Otti Berger, who developed a tactile theory of fabric. 
This haptic discourse of textural, luminous materialities involves a pioneering theorization of the screen and of the activity of projection. Rather than ignoring the screen or underplaying its function, Moholy-Nagy devotes significant conceptual thinking to its architecture. He recognizes the powerful presence of the screen as a surface and considers it a material in itself, an entity that should be looked at not only in relation to figuration. In this view, the screen comes into play as a veritable material siting for the image. And in this sense, the screen, as a space, can be 'architected' creatively. In a chapter of Painting Photography Film significantly titled 'Simultaneous or Poly-Cinema', Moholy-Nagy suggests that the screen could be configured in different forms and made into diverse planes and shapes:

One can, for example, visualize the normal projection plane being divided by a simple adapter into different obliquely positioned planes and cambers, like a landscape of mountains and valleys. [...]

Another suggestion for changing the projection screen might be: one in the shape of a segment of a sphere instead of the present rectangular one. [...] More than one film [...] would be played on this projection screen; and they would not, indeed, be projected on to a fixed spot but would range continually from left to right or from right to left, up and down, down and up, etc. [...] Two or more events [...] will [...] combine and present parallel and coinciding episodes. ${ }^{18}$

In Moholy-Nagy's imaginative experimentation, the screen ends up being constructed spatially - in the form of a 'landscape'. As such a landscape, this screen has multiple planes and can offer different possibilities for vistas and viewpoints. ${ }^{19}$ The technological expansion of planes that is possible on screens signals an increased capacity 'for simultaneous acoustical and optical activity'. ${ }^{20}$

As Moholy-Nagy relates the screen to a modern landscape of simultaneity, he does not disregard the acoustical dimension. The surface of the screen reflects the modern capacity to articulate a landscape that is also made of different impressions of sounds. Such capacity is embodied in the metropolis, which is itself understood as a screen. For Moholy-Nagy, the surface of 
the screen ultimately has an acoustical texture. The artist likens it to the simultaneous array of sounds made by the means of transport that mobilize an urban landscape. In this tonal sense, the landscape of Moholy Nagy's poly-cinema becomes, indeed, polyphonic.

Conceived as a polymorphic '-scape', this landscape-screen is subjected to inventive planar mobilization. Moholy-Nagy's screen not only can be architected in different shapes; it also can be split and multiplied. Challenging the figure of the single screen or the fixed geometry, the artist champions multiple projections. He imagines screening 'a sequence of pictures simultaneously' and 'projecting extra prints of the running filmstrip on to the screen through projectors standing next to one another.' ${ }^{21}$ This multiple screen is a tensile surface. It is a membrane that can enable simultaneity, parallelism, and the polyphonic combination of heterogeneous situations.

Understood as such a landscape, the surface of this polyphonic screen activates a movement of spectatorial positions. Moholy-Nagy pushes the conceptual experimentation of the screen in order to mobilize the actual process of film projection. When he suggests forging screens of different geometries and proposes combining them in simultaneous projections of movement, it is in order to arrive at a different architecture of viewing. The screen is thus understood as a complex location, and it is eventually even freed from being a fixed place. Creating a screen that is a landscape in motion, Moholy-Nagy ultimately conceives of the possibility of freeing the projection screen itself from static placements, thus polyphonically imagining a mobile, 'expanded' cinema.

\section{Reflections on the Screen's Polyphonous Membrane}

In the avant-garde experiments and experimental theory of László MoholyNagy, we find many elements of connection with the experimental and 'expanded cinema' practices of the 196os, which in turn relate to some of the directions that today's media practices and artistic enterprises have taken with regard to the screen. ${ }^{22}$ Although still lacking in sustained

21 Ibid.

22 A number of experimental and 'expanded cinema' practices of the 1960 os built on the ideas of earlier avant-gardes regarding screening. Think of Andy Warhol's Exploding Plastic Inevitable, with its multi-screen visual and sound environments; Stan VanDerBeek's Movie-Drome; Paul Sharits' locational film environments; or Harry Smith's screenings on projectors standing next to one another. For a survey of this rich field of experimentation, see Leighton, Art and 
theorization as an entity, especially outside of figuration, the screen has by now, as I have noted, come to inhabit our lives in multiple forms. In fact, the geometry of the screen has become not only ever-present but also multiform. The entrance of the digital has made it possible to articulate the potential of the screen to hold different planes, host simultaneity, and enhance combinations and connectivity. The diversified language of the screen has turned into an actual material condition of our existence. In an articulated simultaneity, virtual movements are taking place on an environment of screen surfaces.

The art gallery and the museum have also become sites of screening experiments that resonate strongly with earlier avant-garde practices. ${ }^{23}$ Screen-based new media practices work with the creative potential of screening by expanding the size of the screen and its capacity and by magnifying and multiplying the number of screens. Split screens, double or multiple projectors, and expanded relations between multiple screens are now fully in place. The act of screening has also incorporated other polyphonic potentials and more mobility. Virtual movement is pursued, and this also means less fixity in the conceptual configuration of the screen, which becomes the surface of a mediatic transformation. Screen space becomes conceptually lighter and more tensile, and the texture of the screen changes to incorporate fluidity. This aesthetic phenomenon that I call 'the surface tension of media' includes the creation of 'screen-membranes' and 'curtain-scrims' in the art gallery. ${ }^{24}$ Made of translucent fabric, this contemporary screen is conceptually closer to a canvas, a sheet, a shade, or a drape. Partition, shelter, and veil, it can be a permeable material envelope, and it is habitable space. In this textural sense, then, the contemporary screen refashions the very material archaeology of the medium that I outlined earlier. Art rejoins film as a place in which to reflect on the transformative architecture of screening and on the stability and mobility of its fabrication.

To think of screening in this sense also means to recognize that there is a movement between art forms occurring on the surface of the screen. When Moholy-Nagy emphasized light as a way to texturally connect painting

the Moving Image, including a manifesto by VanDerBeek, as well as essays by Bruce Jenkins on Fluxfilms, Branden Joseph on Warhol, Federico Windhausen on Sharits, and Beatriz Colomina on the Eameses' multimedia architecture for the 1959 American National Exhibition in Moscow, which was itself a site of such mediatic experiments. See also Youngblood, Expanded Cinema; Iles, Into the Light; Shaw and Weibel, Future Cinema; and Walley, 'Identity Crisis', pp. 23-50.

23 For a treatment of screen-based art, see, among others, Mondloch, Screens; and Balsom, Exhibiting Cinema in Contemporary Art.

24 See in particular Chapters 3, 4, and 5 of my book Surface. 
to photography, architecture, and film, he created experiments that find correspondence in contemporary experimentation with the surface of light as a material form of passage. This connective thread, which involves linking together the luminous material condition of viewing in the visual arts and media, is very much alive. New material relations arise today between art, architecture, fashion, design, film, and new media, in a range of practices that, in pushing the boundaries of their specific mediums, pursue new forms of materiality through the use of such materials as technologies of light. Transitive movements of the arts reside today within haptic, luminous environments of projection. In the ebb and flow of technological change, the art of projection has found new ways to hold our fascination in intermedial forms.

\section{Luminous Opacity: Screen, Window, Wall}

This contemporary refashioning of surface in the art of projection also suggests a fundamental rethinking of the architecture of wall, window, and screen as permeable membranes. In my view, this emergent screenmembrane performs as a connective tissue, turning architecture and art into pliant planes of moving images. Let me offer some concrete examples of this 'surface tension of media' in our times. To illuminate how materiality is dwelt upon as a surface condition, I will focus on the luminous use of visual technology and new media practiced in public art by Krzysztof Wodiczko. Since 1980, this Polish-born artist, who lives in New York City and Cambridge, Massachusetts, has produced more than eighty large-scale public projections on buildings, in many different countries. ${ }^{25}$ Wodiczko uses the medium of projection to make the face and façade of architecture into a dense surface, creating a permeable site for mediated experiences of memory, history, and subjectivity. In this way, he exposes the actual architecture of projection, in material, mediatic mediation.

Wodiczko's projections sensitize us to the texture of the surface onto which the image is projected. The space onto which these images are projected is never invisible but always rendered tangible. In The Tijuana Projection (2001), for example, the artist animates the human body in projection against the body of building form. The face of a woman mouthing her story is projected

25 See, among others, Wodiczko, Critical Vehicles; and Turowski, Krzysztof Wodiczko. For a sustained reading of this artist's work, see Deutsche, 'Krzysztof Wodiczko's Homeless Projections', pp. 3-48. 
as if her facial skin were adhering to the spherical surface of the dome of the city's Centro Cultural. In Hiroshima Projection (1999), gesticulating hands are projected in close-up onto the moving surface of a river, in this way appearing to activate mnemonic flow. In this work, the moving image is carved out of the material surface of the architecture that supports it, animates it, and moves it. A form of mediation, the architectural surface acts for Wodiczko as a partition: that is, it functions as a visible screen.

Guests, an installation from 2009, makes this even more evident. Walking into the dark space of the Venice Biennale Pavilion, you thought you were seeing eight windows, scattered on three walls, and, looking up, one skylight. But the walls did not have any openings. These frames were not carved in stone. The windows are projections. They are 'screens' on which one can catch glimpses of the life of immigrants, the 'guests' of the country we are in. If You See Something..., from 2005, was similarly structured. The surface of these imaginary windowed architectures functions as an elaborate form of mediation, for these luminous screens provide access to the personal narratives of invisible citizens. It is significant that the migrants are never seen or heard clearly. They appear as shadows through the light, silhouettes in a digital shadow theatre. The interrelation of visibility and invisibility in society is concretely materialized here, uncovered on the nonexistent panes of glass windows that are dressed as screens. ${ }^{26}$

As we look closely at these walls, which act as windows, we can actually perceive them as screen surfaces. ${ }^{27}$ In order to see, we must navigate through a surface that is visually configured as a dense, white material. A milky, textured substance appears to our senses, and, acting as a cover for the window-walls, it mediates the relationship between seer and seen. In this sense, we perceive the materiality of projection, which is digitally configured to approach screen surface. Closer to a veil or curtain than to a pane of glass, this surface is the actual visual tissue of projection. Thus it is not just the function but also the consistency of these window-walls that is closely related to the fabric of the screen. Through this textural manifestation we can perceive-envisage - the support of the image and its representational medium. The projection screens, far from being invisible, are made palpable as projective matter. And thus as we try to make out the foggy figures of the displaced people and hear their stories through muffled sound, we experience the mediatic quality of the screen as a veiled, and veiling, surface.

26 See Lajer-Burcharth, 'Borders', pp. 32-45; and Lajer-Burcharth, 'Interiors at Risk', pp. 12-21.

27 My critical reading of Wodiczko's work owes much to private and public conversations with the artist, whom I wish to thank. See in particular Bruno, 'Krzysztof Wodiczko'. 


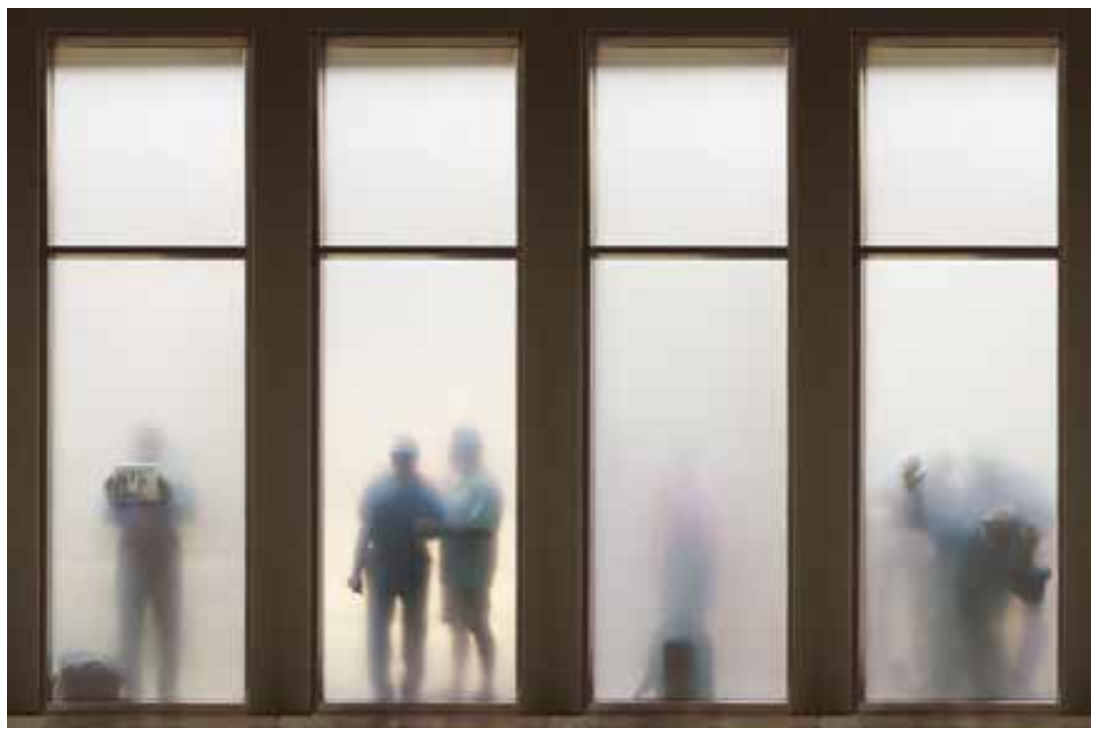

4. Krzysztof Wodiczko, If You See Something ..., 2005. Four projected video images with sound, various durations. Installation view. Courtesy of the artist and Galerie Lelong, New York.

If You See Something... and Guests display the actual analytic material of projection, and because this surface is made physically present, it shows a peculiar quality. In these installations, screens can materially act as membranes. As the figures move in a blur, their contours come in and out of focus, becoming more consistent as they approach the limit of the screen. The effect makes the screen feel like a tissue, a permeable, thin sheet. Such a screen appears to move like a membrane that is being stretched. Wodiczko plays ironically with this permeable materiality as he shows people trying to clean the impossibly foggy substance. Rain falls often, further blurring and veiling the surface. Some visitors to the installation come up to the site of projection as if wishing the space could extend or stretch like a membrane. In turn, the migrants act as if the partition could bend or warp to create a passage, or as if it could be visually traversed, like a veil. They push their bodies up to the surface and hold up hands, pictures, and objects as if wishing to push them through a layer of tissue. In many ways, this screen is shown to be elastic, flexible, and pliant.

Surface tension occurs here. This membrane is an actual screen also in the sense that it is a partition. On this site of partition, the migrants can negotiate status and story, for this membrane-like surface acts simultaneously as a protective layer and as a wall. There is substance, which is also a form of resistance, in this material of projection. As if to rebel against their status as shadows, the migrants push up against the partition as they would against a real border. But let us not forget that the virtual architecture constructed 
by Wodiczko is also a window; that is, it is the kind of architecture in which positions between inside and outside can be mediated. In this capacity as aperture, the resilient surface does not merely divide but also enables a passage, which finally becomes a potential crossing of borders. Possibilities of openings and a hope for exchange can be sited on this composite, tensile, permeable screen that acts as a membrane.

\section{Atmospheres of Projection}

Recalling the long experimental history of 'light and space' installations, this projective passage refashions the actual form of surface tension that occurs on a film screen. Coated in the material fabric of projection, this is a space of traversal that includes spectatorial projections. As a visitor to this space, one is not safely positioned on the other side of the screen but rather stands on the border, for in order to perceive, one must cross over and project oneself across the threshold. The fabric of this screen is so absorbent that it absorbs the viewer, too, in its surface tension. To look is to feel this tension, challenging who and what is outside and inside. One cannot simply stare at this surface. The tension of this tensile surface forces one to become engaged - to the point of wishing that borders might be crossed and contact might be made through the membrane, across the fabric of the screen. Not only a site of critical distance, this kind of screen is both resistant and embracing because it holds affects in its fabric. Its porous membrane enables the passage of empathy, which is itself a form of projection. In staging an epidermic form of exchange, this surface-membrane thus mediates the potential for relatedness that is inscribed in filmic projection. And so the memory of film comes to the surface in installation form, embodied in digital space.

The indexical quality of celluloid may be no longer with us, but this new pellicular membrane is just as affectively tensile. The digital can hold us in deeply articulated surface tension. Rather than flat dimensionality, a dimension of volume and depth continues to emerge from the surface of the screen in moving-image installations. This sense of material substance is conveyed not only on the screen but also in the spaces of projection. The immaterial consistency proper to both light and air permeates these aesthetic spaces. The visible is here 'a quality pregnant with a texture'. ${ }^{28}$ The atmosphere of projection is thick. It is dense with moody, luminous particles dancing in space, imbued with an air of cloudy, permeable palpability. 
Projection was indeed always an environment, and it is becoming even more of an atmosphere. Screen space is a site haunted by 'the perturbations of surfaces. ${ }^{29}$

To fully sense these textural matters, think again of the material history of the screen and of the surface of design in history. After all, ethereal consistency is the material base of the act of screening. As it emerged from the design of the fire-screen and the window-screen, and then turned into the exhibition space of the magic lantern and phantasmagoria, the idea of projection was in fact, historically, born out of atmospheric surfaces. The act of projection was designed to make images flare out and move, in the way Lucretius envisioned it, surfacing from the fabric of light and the density of air. Early forms of projection were furthermore a weathered kind of space, as the phantasmagoria of projection was imbued with such vaporous things as smoke and fog. Projection was also closely associated with elusive substances such as the hazy, misty quality of shades, silhouettes, and shadows, which were thought actually to materialize on screen. Later on, Moholy-Nagy dreamt of light visions' even in 'open spaces, and on unusual screens, such as fog, gas and clouds' $3^{30}$ It is no wonder, then, that such surfaces of material resistance and permeability, integral to the very activity of screening, would find their own digital substance in a new atmosphere of projection..$^{3}$

In these new viewing chambers, the force of light persists along with shadow play. A place of passage and a point of contact between worlds, the screen is a real medium. It continues to mediate today, crossing the borders of media in surface tension. In the atmosphere of projection, a form of curtaining, partitioning, and partaking of space takes place, beyond medium specificity. The screen itself is reinvented as a material architecture of 'becoming' - the tensile surface that connects and mediates texturally between art forms. Far from being responsible for dematerialization, the persistence of projection in the art gallery continues to refashion mobile, communal architectures of materiality. It even reactivates the public potential of the cinematic mode of exhibition and its experience of the public sphere. And so as the shadow theatre that is cinema is reconfigured and rematerialized architecturally, and the white cube of the gallery turns luminously dark, we are returned to the absorbent, envisioning, relational fabric of projection, displayed on yet another form of screen-membrane.

29 On the painterly significance of this expression, see Didi-Huberman, 'The Imaginary Breeze', p. 280 .

30 Moholy-Nagy, cited in Huhtamo, 'The Sky is (not) the Limit', p. 342.

31 On this subject, see also Païni, 'Should We Put an End to Projection', pp. 23-48. 


\section{Bibliography}

Balsom, Erika. (2013). Exhibiting Cinema in Contemporary Art. Amsterdam: Amsterdam University Press.

Bruno, Giuliana. (2014). Surface: Matters of Aesthetics, Materiality, and Media. Chicago, IL: University of Chicago Press.

- (2007). Public Intimacy: Architecture and the Visual Arts. Cambridge, MA: MIT Press.

- (2007). 'Krzysztof Wodiczko'. An interview for 'In the Open Air: Art in Public Spaces,' a project of Bomb magazine and PBS's Art 21, Sculpture Centre, New York, 29 October 2007. Available at: http://bombsite.com/issues/999/articles/3592. (Accessed 29 April 2015).

- (2002). Atlas of Emotion:Journeys in Art, Architecture, and Film. London and New York: Verso.

—. (1992). 'Streetwalking around Plato's Cave'. October 6o (Spring): 110-129.

Lucretius (Titus Lucretius Carus). (1997). On the Nature of the Universe: A New Verse Translation by Sir Ronald Melville. Oxford: The Clarendon Press.

Deutsche, Rosalyn. (1998). 'Krzysztof Wodiczko's Homeless Projections and the Site of Urban "Revitalization”'. In her Evictions: Art and Spatial Politics. Cambridge, MA: MIT Press, pp. 3-48.

Didi-Huberman, Georges. (2003). 'The Imaginary Breeze: Remarks on the Air of the Quattrocento'.Journal of Visual Culture 2, no. 3 (December): 275-289.

Elcott, Noam. (2011). 'Rooms of Our Time: László Moholy-Nagy and the Stillbirth of Multi-Media Museums'. In Screen/Space: The Projected Image in Contemporary Art, edited by Tamara Trodd. Manchester: Manchester University Press, pp. 25-52.

Friedberg, Anne. (2006). The Virtual Window: From Alberti to Microsoft. Cambridge, MA: MIT Press.

Huhtamo, Erkki. (2009). 'The Sky is (not) the Limit: Envisioning the Ultimate Public Media Display'. Journal of Visual Culture 8, no. 3: 329-348.

- (2004). 'Elements of Screenology: Toward an Archeology of the Screen'. ICONICS: International Studies of the Modern Image 7: 31-82.

Iles, Chrissie. (2001). Into the Light: The Projected Image in American Art 1964-1977. New York: Whitney Museum of American Art.

Kuhn, Annette, ed. (2009). Screen 50, no. 1 (Spring), special issue 'Screen Theorizing Today.'

Lajer-Burcharth, Ewa. (2009). 'Borders'. In Krzysztof Wodiczko: Guests, by Ewa Lajer-Burcharth, John Rajchman, Bozena Czubak, and Kzrysztof Wodiczko. New York: Charta Books, pp.32-45. 
. (2008-09). 'Interiors at Risk'. Harvard Design Magazine 29, special issue 'What about the Inside?' (Fall-Winter): 12-21.

Le Corbusier. (1931). Towards a New Architecture, translated by Frederick Etchells. London: John Rodker.

Leighton, Tanya, ed. (2008). Art and the Moving Image: A Critical Reader. London: Tate Publishing.

Lindsay, Vachel. (2000). The Art of the Moving Picture. New York: Modern Library. Merleau-Ponty, Maurice. (1968). 'The Intertwining-The Kiasm'. In The Visible and the Invisible, translated by Alphonso Lingis. Evanston, IL: Northwestern University Press, pp. 130-155.

Moholy-Nagy, László. (1969). Painting Photography Film, translated by Janet Seligman. Cambridge, MA: MIT Press.

- (1936). 'Light Architecture'. Industrial Arts 1, no. 1 (Spring): 15-17.

Mondloch, Kate. (2010). Screens: Viewing Media Installation Art. Minneapolis, MN: University of Minnesota Press.

Païni, Dominique. (2004). 'Should We Put an End to Projection?'. October 110 (Fall): 23-48. Paul, William. (1996). 'Screening Space: Architecture, Technology, and the Motion Picture Screen'. In The Movies: Texts, Receptions, Exposures, edited by Laurence Goldstein and Ira Konigsberg. Ann Arbor, MI: University of Michigan Press, pp. 244-274.

Rancière, Jacques. (2007). The Future of the Image, translated by Gregory Elliott. London: Verso.

Shaw, Jeffrey, and Peter Weibel, eds. (2003). Future Cinema: The Cinematic Imaginary after Film. Cambridge, MA: MIT Press.

Smith, T'ai. (2006). 'Limits of the Tactile and the Optical: Bauhaus Fabric in the Frame of Photography'. Grey Room 25 (Fall): 6-31.

Somaini, Antonio. (2010). 'Fotografia, cinema, montaggio. La "nuova visione" di László Moholy-Nagy'. In Pittura Fotografia Film, translated by Bruno Reichlin. Turin: Einaudi, pp. ix-Ixi.

Turowski, Andrzej, ed. (2005). Krzysztof Wodiczko: Pomnikoterapia. Warsaw: Zacheta National Gallery of Art.

Walley, Jonathan. (2011). 'Identity Crisis: Experimental Film and Artistic Expansion'. October 137 (Summer): 23-50.

Wasson, Haidee. (2007). 'The Networked Screen: Moving Images, Materiality, and the Aeshetics of Size'. In Fluid Screens, Expanded Cinema, edited by Janine Marchessault and Susan Lord. Toronto: University of Toronto Press, pp. 74-95. Wodiczko, Krzysztof. (1999). Critical Vehicles: Writings, Projects, Interviews. Cambridge, MA: MIT Press.

Youngblood, Gene. (1970). Expanded Cinema. New York: E.P. Dutton. 
About the Author

Giuliana Bruno is Emmet Blakeney Gleason Professor of Visual and Environmental Studies at Harvard University. She is internationally known for her interdisciplinary research on visual arts, architecture and media. Her book Atlas of Emotion: Journeys in Art, Architecture and Film (Verso, 2002, reprint 2018) has gained several prestigious recognitions, including the Kraszna-Krausz prize in Culture and History. Bruno is also the author of Streetwalking on a Ruined Map (Princeton University Press, 1993) — winner of the Society for Cinema and Media Studies book award—and Public Intimacy: Architecture and the Visual Arts (MIT, 2007), and has contributed to numerous monographs on contemporary art published by the Guggenheim Museum, the Whitney Museum, and the Museum of Modern Art (MoMA). In her latest book, Surface: Matters of Aesthetics, Materiality, and Media (University of Chicago Press, 2014), Bruno revisits the impact of surface and materiality in contemporary visual art and culture. 